After a year and a half of denials, Woo Suk Hwang admitted last Thursday that his stemcell research used eggs from paid donors and junior members of his team. Although planning to continue his research, Hwang said he would quit his other positions.

Despite the confession, which shocked South Korea and the global stem-cell research community, many have remained supportive. The Korean government has promised to continue his funding at Seoul National University, and nearly 800 women have signed up to donate eggs to his research through a nonprofit foundation. But critics are pushing for a deeper investigation into what happened.

The eggs in question were used in the first successful attempt to derive stem cells from a cloned human embryo (W. S. Hwang et al. Science 303, $1669-1674 ; 2004)$. The study was hailed worldwide. But three months later, Nature reported daims from one of Hwang's graduate students - later retracted - that she and another junior researcher in the lab had donated eggs (see Nature 429, 3; 2004). The controversy was reignited last month, when the fertility doctor who supplied Hwang with eggs, Sung Il Roh, admitted to paying at least 20 women for their donations.

Egg donation is invasive and painful, and can have serious side effects. Paying donors is now illegal in Korea, although it was not at the time of Hwang's study. And receiving donations from subordinates raises a variety of ethical problems, including the spectre of coercion.

Until 24 November, Hwang had denied everything. Then, in a press conference aired live on all three of the country's main television networks, he admitted that eggs from his researchers and paid donors had been used. A downcast Hwang told the Korean media that he had lied about the researchers' donations to protect their privacy. "I am so ashamed. I will not attempt to justify what I did," he said.

Critics are still concerned, however (see page 532). Young Mo Koo, a bioethicist at Korea's University of Ulsan, says Hwang has not addressed enough questions about his involvement with the egg donors: "There needs to be an investigation by an independent party."

For example, Hwang claims to have known nothing of the payments until a few days before his confession - when Roh told him. Yet in April 2004 he told Nature that he had himself "arranged" many of the donors at the hospital concerned. Roh was awarded $40 \%$ of the patent resulting from the paper, on which he was not an author. He says he does not know why Hwang offered him so much but that it was not compensation for providing the eggs. "I don't need any rewards, ${ }^{,}$he says. Hwang has not disclosed his expenditures or budget for the project, saying only that all funds came from private sources.

The extent to which a junior member of his laboratory might have felt pressure to donate is also under debate. The student spoken to by Nature last April showed no signs of having been coerced by Hwang. During a 28-minute interview, she proudly described how her patriotism and concern for those with spinal injuries had inspired her to donate. Nature was unable to contact the other researcher, who is since thought to have moved to the United States. But according to Roh, she felt obliged to donate after making mistakes early in the experiment that wasted eggs and set the team back by months. "I think it's a beautiful story," Roh told Nature, referring to both women's donations.

Insoo Hyun, a bioethicist at Case Western Reserve University in Cleveland, Ohio, has worked with Hwang's group on bioethics protocols. Hyun says the students' accounts prompt hard questions about what coercion is. ${ }^{\circ}$ To some degree, in Korean society, if you make a mistake you must make good on it somehow," he says. "It's a grey area."

Many Koreans have already sided with Hwang. On 26 November, demonstrators gathered outside the Munhwa Broadcasting Company in Seoul to decry the firm's lack of patriotism after it aired evidence that Hwang

\title{
Antarctic ice puts climate predictions to the test
}

\section{A record of greenhouse gases spanning the past 650,000 years made headlines around the globe last week. The painstaking work proves that levels of car bon dioxide and methane in the atmosphere today massively outstrip those of the pre-industrialera. But it also reveals how little we understand about the way in which these gases influence global climate.}

Researchers from the European Project for lce Coringin Antarctica (EPICA) sampled air bubbles preserved inside a 3,000-metre icecore drilled at Dome $\mathrm{C}$ in eastern Antarctica. The data show previous fluctuations in levels of greenhouse gases in unprecedented detail (see Science 310, 1313-1317; 1317-1321; 2005).

Before the results were in, Eric Wolff, a physical scientistat the British Antarctic Survey in Cambridge,UK, set whatcame to be known as the 'EPICA challenge'. From previously published data on the prehistoric temperature record, could anyone predict the EPICA gas record? He published the resulting efforts in September (Eos 86,

341-345; 2005).

Now that the actual figures have been published, Wolff says all of the

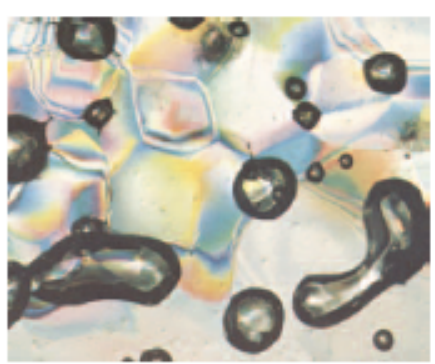

Bubble whammy: gas in ancient ice shows global models need work.

models correctly predicted that carbon dioxide levels in the period covering the four most recentice ages would be higher than between previous ones. The surprise was that entrants whoused global models, such as Peter Köhler of the Alfred Wegener Institute in Bremerhaven, Germany, did less well than those whoconsideredonly the Southern Ocean, such as Didier Paillard of the Laboratory of Climate and Environmental Sciences in Gif-sur-Yvette, France.

This highlights the degree to which the Southern Ocean influencesglobalgreenhouse-gas levels - owing to its size and the fact that its cold, deep waters put large amounts of dissolved carbon dioxide out of circulation. But the less 
IMAGE

UNAVAILABLE

FOR COPYRIGHT

REASONS

Woo Suk Hwang admits to

the world that he used eggs

donated by his juniors.

had lied. Eleven out of twelve advertisers have dropped their contracts with the company, according to the JooAng Daily.

Although $\mathrm{Hwang}$ has promised to resign his directorship of the Seoul-based World Stem Cell Hub, the international cell-sharing initiative says it will hold his position for him.

Some stem-cell researchers and potential collaborators in other countries also seem willing to forgive and forget. One US scientist, who would not speak on the record for fear of appearing insensitive to ethical issues, says it is hypocritical to punish Hwang for paying donors when infertile couples in the United States often pay tens of thousands of dollars for eggs. "Is it $\mathrm{OK}$ to buy them for one purpose and not another?" he asks.

The fact that Hwang lied may make it hard for him to regain his international prestige. "Now it becomes an issue of whether one has a collaborator whose integrity one can trust, and that is a very fundamental issue," says Evan
Snyder, a neuroscientist at the Burnham Institute in La Jolla, California, who has suspended plans to work with with Hwang. Hyun agrees: ${ }^{\alpha}$ Hwang has a credibility issue now. The dust hasn't settled."

"It's a useful cautionary tale," adds Larry Goldstein of the University of California, San Diego. He argues that the community should create a set of international ethical guidelines to protect patients and donors.

David Cyranoski and Erika Check successful performance of Köhler's model, which includes factors such as the effects of vegetation, shows that comprehensive models of the carboncycle need improvement, says Wolff.

Difficulties in predicting future climate are compounded by the fact that greenhouse-gas levels are set to go off the scale relative to those in the EPICA record. Carbon dioxide did not exceed 290 parts permillion in the 650,000 years before the advent of fossil fuels - it now standsat 375 parts per million, and many policymakers are discussing strategiesto stabilize it at an ultimate level of 550 . "It seems like a dangerous experiment tome," says Wolff.

The results of that 'experiment' are already starting to come in. In the past week alone, several groups have warned that the Atlantic Ocean is in trouble (see 'Atlantic feels climate heat'). Researchershope the findings will focus world leaders, who are currently gathered in Montreal, Canada, to plan emissions policies following the end of the first phase of the Kyoto Protocol in 2012.

"It's clear that we need to stabilize greenhouse gases at a level that allows food production but avoids dangerous interference with the climate," says Thomas Stocker of the University of Bern, Switzerland, who led the latest EPICA analysis. "This cannot be done by quick fixes." Michael Hopkin

\section{Atlantic feels climate heat}

The Atlantic Ocean is already suffering the consequences of global warming, reported climatologists from around the world in the past week. Here are examples of what they have found.

- The North Atlantic is losing its ability to absorb carbon dioxide from the atmosphere. This means that future emissions are more likely to cause global warming, said researchers at a meeting of the European CARBOOCEAN project in Amsterdam.

- The carbon dioxide that does dissolve in the ocean makes it more acidic, threatening to corrode the calcareous exoskeletons of animals such as corals, attendees told the meeting. The Atlantic soaks up some $25 \%$ of all carbon dioxide emitted into the atmosphere.

- The system of currents that includes the GulfStream - which warms the temperate regions of Europe - is weakening. Research suggests its flow has reduced by a third since 1957 (see page 655). This weakening is evident not in the Gulf Stream itself (the fictional failure of which was dramatized in the film The Day After Tomarrow), butin themovement of cold, deep waters. 